\title{
A Chinese Aesthetics Reading of Wordsworth's Tintern Abbey ---with a Comparison to Chunjiang Huayue Ye
}

\author{
BAI Li-bing \\ School of Foreign Languages, Central University of Finance and Economics \\ PO box 100081, 39 Xueyuannanlu, Haidian, Beijing, China
}

Received: 26-12-2013

doi:10.7575/aiac.ijclts.v.2n.2p.11
Accepted: 02-02- 2014

Published: 01-04-2014

URL: http://dx.doi.org/10.7575/aiac.ijclts.v.2n.2p.11

\begin{abstract}
The nature poetry written by English Romantic poet Wordsworth is a milestone in English literary history. Its inbuilt aesthetics is much similar with that of ancient Chinese Mountain-Water poetry. The most remarkable aspect is the fusion of feeling and scene, in which philosophy, aesthetics, and poetics are interwoven into a thematic unity. In this perspective, one Chinese nature poem Chunjiang Huayue Ye written by early Tang Dynasty poet Zhang Ruoxu can be well compared. This mutual illumination not only yields a dialogical channel, more importantly, it also discovers the potential values of the two: first, Wordsworth's unique aesthetical awareness is forwarded; second, it helps to globalize and modernize ancient Chinese literary theory.
\end{abstract}

Keywords: Wordsworth; Nature poetry; Chinese aesthetics; Comparison

\section{Introduction}

Chinese Mountain-Water Poetry (山水诗), or nature poetry, has a long tradition. But the correspondent poetic genre in English literature started very late. Poetry before English Romanticism seldom depicted natural scenes. English Romantic poet William Wordsworth (1770-1850) had a sharp perception on nature, and wrote several beautiful nature poems. These nature poems are also among the best in English poetry, such as Tintern Abbey, Daffodils, and Westminster Bridge, etc. Wordsworth's nature poetry is not only a milestone in English history of poetry, but also a masterpiece according to ancient Chinese aesthetics of nature poetry, so it can be well interpreted by Chinese poetic theory. This article mainly focuses on Wordsworth's Lines Composed a Few Miles above Tintern Abbey (best known as Tintern Abbey), and brings one Chinese nature poem Chunjiang Huayue Ye (《春江花月夜》, The River, Moon, Flower in a Spring Night) written by early Tang Dynasty poet Zhang Ruoxu (张若虚, about 660-720) into comparison.

This article utilizes the methodology of literary hermeneutics to evaluate Wordsworth's nature poetry from a perspective of Chinese traditional aesthetics. The justification for such an intercultural dialogue lies in the universality of aesthetical perception of human mind---that is, a common poetic heart. Pauline Yu said that many concepts of poetry have transcended the boundaries of history and culture, so they are by no means belong to a certain time or place ${ }^{1 .}$

This approach of mutual-hermeneutics digs a channel for the free interchangeability and mutual illumination of common poetic experiences in different national literatures. In the past, scholars of comparative literature usually employed western literary theories to interpret ancient Chinese texts. This article tries the opposite approach, seeking the possibility of using Chinese literary theory to analyze western texts.

In his influential book The Mirror and the Lamp, Romantic Theory and Critical Tradition, M. H. Abrams proposed a diagram to illustrate the trend of western literary criticisms. The four themes: the universe, the reader, the artist, and the work itself offered basic standpoints for the demarcation of literary criticisms. ${ }^{2}$ Configuration theories like this are common in the west, but rare in Chinese literary criticism. James J. Y. Liu adapted this diagram in his interpretation of Chinese critical tradition. ${ }^{3}$ Though a little alien categorically, he made a monumental study that gave a countable way to pigeonhole Chinese literary criticisms, which have been regarded as unsystematic empiricisms in the west. Both Abrams and James J. Y. Liu considered the fusion of feeling and scene is the highest achievement in nature poetry, in which philosophy, aesthetics, and poetics are interwoven into a thematic unity.

Among Chinese classics, The Book of Changes (易经) first used nature imagery to symbolize human affairs. Nature imagery in The Book of Poems (诗经) became the media for bi (比，analogy) and xing (兴，inspiration); later Confucian scholars personified it in Bide ( 比德 ). A free employment of nature imagery to express feelings did not come until the Six Dynasties (229-589AD). The age of Six Dynasties was the second Renaissance in Chinese literary history, among social upheavals and quick succession of dynasties, the different schools of thoughts surged, literature got its independence, and literary aesthetics germinated. Poetry in this time deviated from the moralizing tradition of Han dynasty, the genre of natural scene-eulogizing poetry began to take place. This acted as a seminal force for the flourishing of nature poetry in Tang dynasty. Poetry before Tang dynasty was mainly narrative, the descriptions of feeling and scene were distinctly separated, like Xie Lingyun's (谢灵运，385-433AD)four-stepped poetry of narration, description, expression, and reasoning. The later five-character-line poetry, or Wujue (五绝, classical Chinese genre of 
poetry with four five-character lines, came into being in Tang Dynasty) restricted by its length, divorced from the Han dynasty narrative style. It began to put great theme in laconic words, entrust feeling in the description of natural scenes. In Tang dynasty, the poetic system of rhyme and meter became more sophisticated, the construction of poetic imagery

also made big breakthroughs; nature poetry reached the fusion of feeling and scene. Here, the word 'fusion' does not simply mean a combination, in which the description of feeling and scene are just physically overlapped; it is rather an organic whole without any alienation. The fusion of feeling and scene was regarded as the highest achievement in Chinese nature poetry. The nature poetry written by English poet Wordsworth also deserves a high regard in this perspective, his famous nature poem Tintern Abbey serves as a good example.

\section{Fusion of Feeling and Scene in Tintern Abbey}

The poets of English Romanticism widely employed nature imagery to express their feelings; they made the peak accomplishment in this technique. It is in the age of Romanticism when the fusion of feeling and scene in lyrical poetry came into being in western literature. Wordsworth's best nature poems adroitly manipulated nature imagery and reached the true fusion of feeling and scene. Abrams said, "The poet's (Wordsworth) spontaneous overflow of feeling, provided that the appropriate associations between thoughts and feelings has been established by the poet in advance."4

First, Wordsworth rejected the imitation of nature, "it is a violation of the poet's true intention to observe accurately and describe realistically." Formal likeness or graphical description of nature was the infant stage of aesthetic appreciation. At this point, Wordsworth came in accordance with the nineteenth-century impressionists, who were not committed to meticulous paintings. Wordsworth recorded in his poetry the sound he heard, the image, line and color he saw, so his poetry emphasizes the environmental impression to human sensory organs, and the mental activity stirred by those impressions." Wordsworth held that "the passions of men are incorporated with the beautiful and permanent forms of nature." In 1798, he wrote in the poem Lines Written in Early Spring, "To her fair works did Nature link / the human soul that through me ran." This kind of combination of feeling and nature imagery is Wordsworth's predominant pursuit: "image and feeling intermingled in the heart, image is not a far-fetched contrivance, but should elicit feelings as natural as breath." ${ }^{8}$ In the end of the poem $A$ Night-Piece, ${ }^{9}$ he wrote:

At length the Vision closes, and the mind,

Not undisturbed by the delight it feels,

Which slowly settles into peaceful calm,

Is left to muse upon the solemn scene.

Wordsworthian fusion of feeling and scene is best showed in Lines Composed a Few Miles above Tintern Abbey. ${ }^{10}$ Tintern Abbey is a medieval temple by the river Wye in southwest England. Wordsworth visited it in 1793, and revisited with his sister Dorothy in 1798, when the poem was composed. Five years departure from the old haunt aroused the poet's all sorts of feelings about nature, life, and love. The poem starts with descriptions of natural scenes, and gradually infuses emotions until reaches its climax:

Five years have past; five summers, with the length

Of five long winters! And again I hear

These waters, rolling from their mountain-springs

With a soft inland murmur. (1-4)

The Shangri-la scenery along both sides of the Wye River is the poet's nostalgic obsession. Now he is sauntering over the long-cherished landscape, the tired out mentality and physicality find a resting home, all worldly vexations are washed away. The long gone innocence and ecstasy returned to him, it is a blessing from nature.

---nor less, I trust,

To them I may have owed another gift,

Of aspect more sublime; that blessed mood, (35-37)

The perfect harmony of nature signifies a lofty moral principle that absorbs the inquiry of every meditative mind. Only by thoroughly mixed with nature can one feel its beauty, majesty, and innocence. Nature refined the poet's sentiment and cured his mental wound. Now, with subdued passion and molded maturity, he knows how to observe nature, which brings him not only sensory delight, but also heartfelt excitement.

\section{And I have felt}

A presence that disturbs me with the joy

Of elevated thoughts; a sense sublime

Of something far more deeply interfused,

Whose dwelling is the light of setting suns,

And the round ocean and the living air,

And the blue sky, and in the mind of man;

A motion and a spirit, that impels 
All thinking things, all objects of all thought,

And rolls through all things. (93-102)

The virtue incorporated in nature aroused sympathy of the sentimental poet. He finds repose for his heart and receives the wordless instructions. Here and now, indulged in this extramundane fairyland with his beloved, he cannot expect more from life. Nature serves as the source of their joy. Despite his outstanding talent, the poet just cannot fully express his love for nature.

---and this prayer I make,

Knowing that Nature never did betray

The heart that loved her; 'tis her privilege,

Through all the years of this our life, to lead

From joy to joy--- (121-125)

Nature's broad mind accommodates the two affectionate hearts, and bestows them the courage to face all hardships in life. By now, the poet is completely lost in the dreamland of the fusion of feeling and scene; he cannot differentiate which is which. The bright moonlight and gentle breeze all become the incarnation of his beloved. Love and nature are symphonized into a divine melody. The end portion of the whole poem is a sincere expression of sentimentality: while in great happiness, the sensitive poet regrets for the transience of happy time and beautiful scenery. He is even overwhelmed by sorrow, for he thinks that death will eventually take away his beloved forever. Nevertheless, he is consoled by the eternal nature, a forever bearer of witness here. He believes that his life and love can be eternized by his deistic faith.

Nor, perchance---

If I should be where I no more can hear

Thy voice, nor catch from thy wild eyes these gleams

Of past existence---wilt thou then forget

That on the banks of this delightful stream

We stood together; and that I, so long

A worshipper of Nature, hither came

Unwearied in that service; rather say

With warmer love---oh! With far deeper zeal

Of holier love.--- (146-155)

It is the combination of the beautiful nature and the poet's passionate love that produced this poem of tremendous momentum and far-reaching implications. Emotion is conveyed by a medium of scenic description, which in return sheds light of emotion in every line. The internal and the external are melted in smooth and graceful literary style. Chinese classical literary criticisms talk a lot about the depiction of feeling and scene in poetry; most of them regard high the fusion of the two. Xie Zhen (谢榛, 1495-1575 AD) wrote in the book Simin Shihua (《四溟诗话》),

"Feeling and scene are the basis of poetry writing, neither can be sufficient alone, the two are indeed compatible--what can be seen is the same, but the inner responses are different. One should try to reconcile the internal and external and make them interchange freely in one's heart. Poetry derives from the combination of the medium of scene and the genesis of feeling.” (作诗本乎情景，孤不自成，两不相背......观则同于外，感则异于内。当 自用其力，使内外如一，出入此心而无间也。景乃诗之媒，情乃诗之胚，合而为诗。 $)^{11}$

Wang Fuzhi (王夫之, 1619-1692) also wrote, “Although feeling and scene are separated by internal and external, scene embodies feeling, and feeling creates scene; sadness and happiness of feelings meet the flourishing and withering of scenes, they actually overlap and mutually dependent." (情景虽有在心在物之分，而景生情，情生景，哀乐之触， 荣悴之迎，互藏其宅。《姜斋诗话·卷一》) ${ }^{12}$ Tintern Abbey is not simply a superficial record of the poet's sentimentality; its artistic transcendence converges with Chinese poetics and aesthetics.

Wai-lim Yip once compared the poetic expression of Tintern Abbey and The Vale of Singing Birds (《鸟鸣涧》) by Wang Wei (王维，701-761). ${ }^{13}$ He overlooked the stylistic differences. Wujue is confined by its length; the poet must finish his composition in merely twenty Chinese characters, so concision and vividness are inevitable choices. In Tang Dynasty, the poetic device of Wujue for manipulating nature imagery was already mature. Wang Wei's Wujue represented the peak accomplishment in artistry; some of his adroit devices were indeed inimitable for English poetry. However, Tintern Abbey, as a long poem bearing the tradition of English language and English aesthetics, is surely a masterwork in the fusion of feeling and scene. At this respect, the poem Chunjiang Huayue Ye written by early Tang Dynasty poet Zhang Ruoxu, is suitable for comparison. This long Chinese poem merges time and space, internal and external, feeling and scene, and carries far-reaching implications. The first eight lines describe an elusive dreamland: the river tide seems like the vast expanse of ocean, moonlight is reflected in the waves, diffused in the forests, and blurred in the vision. A serene and beautiful picture of the spring night by the river is presented: 
In spring, the river tide surges

The moon rises from the vast sea of water.

It shines in the rolling waves

And reaches the rivers everywhere in spring.

The river turns around the oasis,

Flowers diffused the moonlight.

The moon's pale light is like floating frost in the sky,

Alike seem the white sandy shores.

Then the poem focuses on the shining moon, and brings a succession of thoughts pondering on the mysteries of life and the universe. Life is a short period of flying time, all passes away like the flow of water. Nevertheless, in face of the eternal moon, the poet's temporary maudlin is replaced by a sublime thought, like in Tintern Abbey, the poet's sense of loss for the transience of happiness is replaced by a pious love for the eternal nature. The basic tone of Chunjiang Huayue Ye is “sorrowful but not distressed”, (哀而不伤) which is Confucius' comment on the poem “Guanju” (關雎, The Fishhawk) in the Book of Songs, and is regarded as the most appropriate way in poetry to express human sorrows. The moving and enlightening power is lurked behind the peaceful poetic language:

For sky and river blended in a crystal color,

The solitary full-orbed moon hanging on the serene sky.

But who was he first stood by the river and gazed upon the heavenly light?

And when did moon first behold The solitary watcher in the night?

Life passes away in endless generations,

The moon remains the same forever.

The poem moves on and pushes the theme deeper and broader. The moonlight finds the woman parted from her lover, and the flowing water sends her feelings far away. This elicits the lovesickness and homesickness in the second half of the poem. The severed woman's plaintive feeling is demonstrated by the animated movements of the moon. The silence of night even intensifies the assumed sadness. Reflecting feeling through scene is the poet's subtle and superb skill:

For whom the river and moon are waiting?

Only ceaseless water flowing away.

A white cloud drifts across the azure dome;

An insurmountable melancholy shrouded the Green Maple river edge.

Who is sailing the boats to-night?

Beneath the moon which links his lovesickness with home?

Above the home, the moon lingers long,

And shines on the dressing table of his beloved.

The light can neither be blocked by the curtain,

Nor be removed by an expelling gesture.

The couple, under the same moon but hears no voice,

She wants to follow the moonlight to find him.

The last eight lines are about the homesickness of a traveler. The falling flower, flowing water, and waning moon all served to play up the atmosphere. Spring is going away; the solitary traveler can only cherish his hometown in his dreams. The homesick feeling melted in the moonlight, which shines upon the forest by the river. Feeling and scene are interwoven into one torrent to wash off the reader's mind. Especially the last line, with its aesthetical beauty, leaves prolonged aftertaste:

Last night, falling flowers by shady ponds came to her dream,

It is middle spring, but her beloved cannot return to home.

The river is carrying the spring away,

The spring, half gone, is gliding to its rest;

The falling moon moves to the west of the pool.

Now is hiding in the heaven mist,

Cliffs and river stretch to far away.

Who is lucky to return to home in the moon?

The light overflows with the feeling on the trees beside the river. 
Chunjiang Huayue Ye surpasses in both poetic theme and artistry the former object-describing poems, metaphysical poems, and love poems. It combines the feeling, life philosophy, and beautiful nature to create a realm in the fusion of the internal and the external. The five common natural objects, namely spring, river, flower, moon, and night, without the forceful sublimity of great mountains, without lofty spirit of exploits, have aroused the poet's deepest feelings, like that in Tintern Abbey:

\section{---but hearing oftentimes}

The still, sad music of humanity,

Nor harsh nor grating, though of ample power

To chasten and subdue. --- (90-93)

\section{The Internal and the External}

Wordsworth's appeal for the fusion of feeling and scene rendered much influence to the poetry circles. His practice was a sinuous opposition to the mechanics of western philosophy, which regards the world as a separation of internal and external. Ever since Rousseau's objection to the domination of science, and his appeal for returning to nature and justification of human sentiment, the thinking of Romanticism began to develop, artists turned to the beauty resided in commonality and expressed their personal feelings in their works. The nature in Wordsworth's poetry is the native landscape of the lake region in northern England. His nature poetry combines feeling and scene, is the sincere expression of his mentality. Some of his best poems can be rated as consummate work of the fusion of feeling and scene.

Chinese philosophy is based on the harmony of man and universe. The Confucian moderation, Taoist sit-forgetfulness, and Zen Buddhist epiphany all lead to the concordance of man and universe, “the world and I are the same," (万物与我 为一《庄子.齐物论》) not labeled in hierarchies. Thus, guided by this belief of universal harmony, Chinese poetry only needs to voice it in language. English Romantic movement was no less than an ideological revolution; however, the ingrained idea of objectifying nature could not be eradicated. "When Romanticists talk about the union of the internal and the external, they mean to unite two opposite things, (while in the Chinese view, the internal and the external had never been considered as opposites) so they use the words: reconcile, healer, coalescence, and dialogue, it is an effort to synthesize contraries". ${ }^{14}$ Paul de Man (1919-1983 ) asserted that the fusion of internal and external is only a willful thinking of Romanticists; it cannot be realized in poetry. ${ }^{15}$ By close examination, it is easy to find the minute differences between Romanticist recognition of the feeling and scene in poetry and that of Chinese traditional aesthetics.

Impelled by free expression, Romanticists fell into the other extreme: an overemphasis on human sentiments. Irving Babbitt (1865-1933) said that Romanticists tended to regard nature as a plaything of their emotion, "when Werther's mood is cheerful, nature smiles at him benignly. When his mood darkens she becomes for him 'a devouring monster."' ${ }^{16}$ Francis Jeffrey’s (1773-1850 ) criticism to Wordsworth on Edinburgh Review was pertinent:

By imbuing his landscape with personal feeling, Wordsworth puts himself first and this suggests (among other things) that it may be difficult to find an 'intelligible ground of sympathy' between his readers and the 'beings' whose situation he presents. Epistemological confidence and the access which it gives to social sympathies are both overturned by Wordsworth's writing. ${ }^{17}$

Abrams summarized the major intention of expression-oriented literature: a piece of artistic work is by nature the exhibition of the mental world, it is a creation governed by passion, a shared manifestation of the poet's feeling, thought, and emotion. ${ }^{18}$ One scholar of English Romanticism Cao Zuoya stated it more thoroughly:

Romantic 'nature poems' are in fact meditative poems, in which the presented scene usually serves to raise an emotional problem or personal crisis, whose development and resolution constitute the organizing principle of the poem. As Wordsworth said in his prospectus to The Recluse, not nature, but 'the Mind of Man' is 'my haunt, and the main region of my song., 19

Wordsworth's nature poetry is more characterized by an alteration of scene by emotion; this can be traced to his basic views of the world and poetry. First, he firmly believed the existence of an omnipotent and omnipresent God. "Wordsworth was at least consistently religious in his attitude towards the landscape." 20 The poem Influence of Natural Objects $^{21}$ (1799) already showed his reverence to nature and the mighty spirit of universe, and eulogized the mystic power governing nature. Lines Written in Early Spring also shares his pantheistic belief that attributes all natural objects as divine. This is common among western poets. George Brandes (1842-1927) said that Byron imitated Wordsworth's Tintern Abbey when writing Childe Harold's Pilgrimage, but Byron was free from religious principle that might act as an insulator between man and nature, so Byron's spontaneous revelation of his true feeling possessed more affinity with nature. ${ }^{22}$ Second, Wordsworth thought that poets are supermen, they possess all virtues and creative powers of God, "endowed with more lively sensibility, more enthusiasm, and tenderness, who has a greater knowledge of human nature, and a more comprehensive soul, that are supposed to be common among mankind." 23 Most poems of Romanticism, like most criticisms, were a circle drawn to the center of poets. "The connections between subject and object or among objects, which the West has by and large credited to the creative ingenuity of the poet, are viewed in the Chinese tradition as already pre-established; the poet's primary achievement often lies in his ability to transcend, rather than to assert, his individuality and distinctiveness from the elements of his world." ${ }^{25}$ The individualism, elitism, and poet worship in western culture all contribute to the stylistic differences between Chinese and English poetry. 
If nature poetry favors human sentiment more than scene, or introduces artificial elements to interrupt nature's order, there will be obstruction between the reader and nature itself, and the aesthetic value of poetry will be reduced. Rational knowledge may not necessarily conform to the law of nature. The poetic inspiration is not derived from knowledge, which even hinders the poetic inspiration. Keats once talked about his experience: "however it may be, O for a Life of Sensations rather than of Thoughts!" ${ }^{26}$ Jonathan Wordsworth ${ }^{27}$ said: "the internalized forms and images of Nature, which in Tintern Abbey had led through recollection to mystical experience, have come to seem mere littleness; the poet's intellectual life now appears to be an Urizenic fall into division, a creating of distinction and categories in place of sharing in the totality of God." ${ }^{28}$ Wordsworth himself also realized this, he wrote in the poem The Tables Turned: ${ }^{29}$

Sweet is the lore which Nature brings;

Our meddling intellect

Mis-shapes the beauteous forms of thing:---

We murder to dissect. (25-28)

Chinese Taoism, the philosophical origin of Chinese nature poetry, calls to drop off wisdom and intellect, (绝学无忧 )not to pursue the endless knowledge. The Confucian Moderation, in contrast to western esteem of knowledge, denies the detailed logicality. That is why the rationality of Mo $Z i$ faded out of the mainstream Chinese thought. The instinctive aesthetics of Chinese poetry cannot be measured by pure knowledge. For example, “Meng Haoran's knowledge is by far inferior to Han Yu, but his poetry is superior” (孟襄阳学力下韩退之远甚，而其诗独出退之上。一—严旸《沧浪 诗话》) $)^{30}$ “there are housewives and illiterates, occasionally composed one or two lines of verses, which are so good that cannot be emulated by great poets, even if Li Po and Tu Fu come to life again.” (有妇人女子，村氓浅学，偶有一二 句，虽李、杜复生，必为低首者。—袁枚《随园诗话》 $)^{31}$

English poetry emphasizes the imaginative power of poets. Romanticist consideration for both internal and external deviated somewhat from the binary opposition in western philosophy, but a strong self-assertiveness is still evident. Some nature poems are imposed by human awareness, which makes it impossible to forget the self. In the study of Romantic poetry, Hegel commented that oriental poetry lacks human spirit: "(the oriental poetry) assumes an objective tone. The poets do not describe external things as that in his mind, but as things themselves---so it is easy to lose oneself in the boundless world." 32 But Chinese poetry is not subjectively based, it advocates: "things have their own hardness and softness, quickness and slowness, prosperity or adversity. They have the diversity and heterogeneity which may correspond to the poet's different feelings, unless first identifying the properties of things; one cannot be sure about the poet's feelings.” ( 物有刚柔、缓急、荣悴、得失不齐，则诗人之情亦有所寓，非先辨乎物则不足以考其性情。 一胡寅《致李叔易》) Under the influences of humanism and poet-worshipping, English poets, committed to humanistic principle, may feel uneasy to forget self. Here return to Tintern Abbey:

Until, the breath of this corporeal frame

And even the motion of our human blood

Almost suspended, we are laid asleep

In body, and become a living soul:

While with an eye made quiet by the power

Of harmony, and the deep power of joy,

We see into the life of things. (43-49)

The poet has merged himself with nature, without any obstructions. Though not conscious of the existence of body, the soul is still active. He can forget things, but not both things and self. Jonathan Wordsworth said, "(in Tintern Abbey) while laid asleep in body he is especially responsive to the moral influence of external forms." 33

Self-forgetfulness means to mindlessly record nature to present poetic themes, without any artificial distortion. This is a standard for superb nature poetry. Wordsworth wrote in the poem Expostulation and Reply:

Nor less I deem that there are Powers

Which of themselves our minds impress;

That we can feed this mind of ours

In a wise passiveness. (21-24)

The "wise passiveness" is much like the "negative capacity" 34 proposed by Keats. Nature imagery is born capable of showing feelings, what is seen consists the universal Way. Wang Fuzhi wrote a perfect annotation for one of Xie Tiao's poems:

There is a language that dose not touch feelings, but feelings shown all over. This is because eyes and hearts take the lead, not dependent on the written language. "Identifying the returning boats from far away, / recognizing the trees and river behind the lingering clouds." What behind the language is a passionate person looking for the return of his or her beloved. Describing scene as this, the scene is animated and dynamic. ( 语有全不及情，而情自无限 者，心目为政，不恃外物故也。“天际识归舟，云间辨江树’隐然一含情凝眺之人呼之欲出，从此写景，乃 为活景。一王夫之《古诗评选》卷五评谢眺《之宣城郡出新林浦向板桥》) 35

Now read a poem Lily Magnolias Valley (《辛夷坞》)written by Wang Wei: 
On the branch tops they bloom like lotus flowers;

In the mountain, they put forth their pink buds.

Not a soul is visible in the quiet gully,

Flowers open and fall by themselves.

木末芙蓉花，山中发红葶。涧户寂无人，纷纷开且落。

The flowers grow and fall following the nature's law, keep away from worldly considerations. They take in the poet's transcendent mentality at a glance. "The most skilled feeling expression does not alter the thing's vicissitudes to suit one’s sorrows and joys.” (善用其情者，不敛物之荣凋，以益己之悲愉。一王夫之《诗广传·小雅·八》) ${ }^{36}$

Any attempts that mean to remake nature is doomed to disharmony. The consummate art is unaffected and unembellished. This view of art is lauded by Chinese poets who believe that "the Way follows the path of Nature." ( 道法自然 ) Sikong Tu's The Natural Style ${ }^{37}$ in his Twenty Four Styles of Poetry is exemplary:

Bend over anywhere and pick it up, but you can't take it from your neighbors. Go with the Tao, and what you write is fine as spring. It's like meeting flowers in bloom, like seeing the year renew. Once given to you it can't be stolen, but gain it by force and soon you're poor again. In the empty mountain, a hermit collects duckweed after rain, and gains this calm inspiration, moving about unhurried as heaven's potter's wheel ${ }^{38}$. (俯拾即是，不取诸邻。俱道适 往，著手成春。如逢花开，如瞻岁新。真与不夺，强得易贫。幽人空山，过雨采萍。薄言情语，悠悠天 钧。一司空图《二十四诗品·自然》)

Wordsworth's famous saying that "poetry is the spontaneous overflow of powerful feelings" 39 is indeed his life-long but seldom achieved pursuit. Keats also said, "That if poetry comes not as naturally as the leaves to a tree, it had better not come at all.” ${ }^{\text {,4 }}$ The recorded Tang dynasty monk Qingyuan’s（青原行思，671 - 740AD ) practice of Zen Buddhism evolved like this:

When I was not a Zen practitioner thirty years ago, I saw mountains as mountains and rivers as rivers. Later, I came to know intimately the Way of Zen, I saw mountains were not mountains and rivers were not rivers. Now, I have got the Way and come to a rest, I see mountains are still mountains and rivers are still rivers. (老僧三十年前 未参禅时，见山是山，见水是水。及至后来，亲见知识，有个入处，见山不是山，见水不是水。而今得个 休歇处，依前见山只是山，见水只是水。——五灯会元·卷十七》 $)^{41}$

These three phases are three stages of the development of aesthetical taste. In the beginning, the recognition of nature was superficial. Later, meditative power that attempts to find the eternal truth distorted nature's original features. At last, the Zen master suddenly saw the light, that the eternal truth is exactly the reality of nature, which contains the fundamental law, so he gave up meditation, and saw both the form and nature of things at a glance.

Wordsworth said in 1816, "Throughout objects...derive their influence not from what they are actually in themselves, but from such as are bestowed upon them by the minds of those who are conversant with or affected by those objects." 42 The external world seen by the Romantic poets is only an imagery reflected by the mirror of minds; it is a kind of mentality, not the external world. Wordsworth depended on mental power, nature served only as a help for imagination. Chinese aesthetician Wang Guowei (王国维 ，1877-1927) wrote in Renjian Cihua (《人间词话》), “There are realms in which one is involved, the nature is observed by his mind and carries his emotion; there are other realms one is absent, the nature lives by itself, so one cannot distinguish which is nature, which is self.” (有我之境，以我观物，故物皆著 我之色彩。无我之境，以物观物，故不知何者为我，何者为物。） ${ }^{43}$ Here the “the realm one is involved” is a characteristic of English Romantic nature poetry; while "the realm one is absent" is the pursuit of Chinese nature poetry.

\section{Conclusion}

In the past, Chinese scholars in comparative literature mostly employed western literary theory to interpret Chinese texts. Through the reading of Tintern Abbey from a perspective of Chinese aesthetics, and with a comparison to Chunjiang Huayue Ye, proved that the counter-interpretation (using Chinese literary theory to interpret Western texts) in comparative literature is not on possible, but also mutually illuminating. The artistic value, especially the fusion of feeling and scene, of Wordsworth's nature poetry is emerged more clearly than it is in the western literary tradition. Wordsworth's handling of the relationship between internal and external in poetry is innovative in the history of English poetry. His aesthetical perception transcended his own age, and his effort to reach "the realm one is absent" can also be detected in his theory of nature poetry. Classical Chinese literary theory is not well known in the west, but there is always a channel for the communication of literary minds, so comparative literature can contribute a lot to the mutual understanding of different cultures in the world.

\section{References}

Abrams, M. H (1953), The Mirror and the Lamp, Oxford, UK: Oxford UP.

Babbit, I. (1991), Rousseau and Romanticism, New Brunswick: Transaction Publishers.

Beijng daxue zhexuexi (1981), Zhongguo meixueshi ziliao xuanbian (Anthology of Chinese Aesthetics) , Beijing: Zhonghua shuju.

Brandes, G. M. C. (1984), tr. Xu Shigu. Shijiu shiji wenxue zhuliu, v4 (The Mainstream of 19 ${ }^{\text {th }}$ Century Literature), Beijing: Renmin wenxue chubanshe. 
Cao, Zuoya. (1998), The Internal and the External, a Comparison of the Artistic Use of Natural imagery in English Romantic and Chinese Classic Poetry, New York: Peter Lang.

Gill, S. (2003), The Cambridge Companion to Wordsworth, Cambridge UK: The Cambridge UP.

Guo Sh. ( 2001 ) , Zhongguo lidai wenlunxuan (Literary Criticism in Chinese History), Shanghai: Shanghai guji chubanshe.

He Wenhuan. (1981), Lidai shihua (Poetry Criticism of Different Dynasties), Beijing: Zhonghua shuju.

Hegel, G. W. F.h (1997), tr. Zhu Guangqian Meixue (Aesthetics), Beijing: Shangwu yinshuguan.

Keats, J.(1970), The Complete Poems, Harlow, UK: Longman.

Keats, J. (2002), Selected Letters of John Keats. Cambridge: Harvard UP.

Man, P. de (1983), Blindness and Insight, essays in the rhetoric of contemporary criticism, Minneapolis: University of Minnesota Press.

Pu Ji. (1984), Wudeng huiyuan (Collections of Five Schools of Zenism), Beijing: Zhonghua shuju.

Wang F.i (1999), Chuanshan yishu (Posthumous Writing of Wang Fuzhi), Beijing: Beijing chubanshe.

Wang G.i (2003), Wang Guowei xueshu lunzhu sanzhong (Three Academic Writings of Wang Guowei), Beijing: Shangwu yinshuguan.

Wordsworth, J. (1982), William Wordsworth, the Borders of Vision, Oxford UK: Clarendon Press.

Wordsworth, W. (2001), Selected Poetry of William Wordsworth, New York: The Modern Library.

Yang, X. (1996), To Perceive and to Represent: A Comparative Study of the Chinese and English Poetics of the Nature Imagery, New York: P. Lang.

Ye, W. (1992), Zhongguo shixue (Chinese Poetics), Beijing: Sanlian shudian.

Yu, P. (1987), The reading of Imagery in the Chinese Poetic Tradition, Princeton: Princeton UP.

Notes

${ }^{1} \mathrm{Yu}, 1987$, p. 23

2 Abrams, 1955, p. 3-29

3 James J. Y. Liu, 1979. Chinese Theories of Literature. Chicago: University of Chicago Press.

${ }^{4}$ Abrams, 1955, p. 26

${ }^{5}$ Yang, 1996, p. 72.

${ }^{6}$ Wordsworth, 2001, p651

${ }^{7}$ Wordsworth, 2001, p75

${ }^{8}$ Yang, 1996, p72

${ }^{9}$ Wordsworth, 2001, p54

${ }^{10}$ Wordsworth, 2001, p99-103

${ }^{11}$ Guo Shaoyu, 2001, p. 113.

${ }^{12}$ Beijng daxue zhexuexi, 1981, p. 278.

${ }^{13}$ Ye Weilian, 1992, p. 86.

${ }^{14}$ Cao Zuoya, 1998, p. 123.

${ }^{15}$ Man, 1983, p. 187.

${ }^{16}$ Babbitt, 1991, p. 299.

${ }^{17}$ Gill, Stephen, 2003, p. 183.

${ }_{18}^{18}$ Abrams, 1953, p. 20.

${ }^{19}$ Cao Zuoya, 1998, p. 107.

${ }^{20}$ Babbitt, 1991, p. 285.

${ }^{21}$ Wordsworth, 2001, p142

${ }^{22}$ Brandes, 1984, p. 51.

${ }^{23}$ Wordsworth, 2001, p657

${ }^{24}$ Abrams, 1953, p. 112.

${ }^{25} \mathrm{Yu}, 1987$, p. 33.

${ }^{26}$ Keats. Letters, 2002 , p. 54.

${ }^{27}$ Professor Jonathan Fletcher Wordsworth $(1932$ - 2006) was an English academic, literary critic and expert on the Romantic era in literature.

${ }^{28}$ Wordsworth, Jonathan, 1982, p. 219.

${ }^{29}$ Wordsworth, 2001, p. 80.

${ }^{30}$ He Wenhuan, 1981, p. 686.

${ }^{31}$ Guo Shaoyu, 2001, p. 480.

${ }^{32}$ Hegel, 1997, v3, p. 229.

${ }^{33}$ Wordsworth, Jonathan, 1982, p126

${ }^{34}$ Keats. Letters, 2002, P60.

${ }^{35}$ Beijng daxue zhexuexi, 1981, v2, p. 280.

${ }^{36}$ Wang Fuzhi, 1999, v2, p. 762.

${ }^{37} \mathrm{He}$ Wenhuan, 1981, p. 40.

${ }^{38}$ Heaven's potter's wheel in Chinese means the natural and effortless outflow of poetry creation.

${ }^{39}$ Wordsworth, 2001, p. 644.

${ }^{40}$ Keats. Letters, 2002, p. 97.

${ }^{41} \mathrm{Pu}$ Ji, 1984, p. 1135.

${ }^{42}$ Abrams, 1953. p. 54.

${ }^{43}$ Wang Guowei, 2003, p. 30. 